\title{
ZAMIA (ZAMIACEAE) PHENOLOGY IN A PHYLOGENETIC CONTEXT: DOES IN SITU REPRODUCTIVE TIMING CORRELATE WITH ANCESTRY?
}

\author{
J. A. R. Clugaton ${ }^{1,2}$ M. P. Griffith ${ }^{2}$, G. J. Kenicer ${ }^{1}$, \\ C. E. Husby 2 , M. A. Calonje 2 D. W. Stevenson ${ }^{3} \&$ D. P. Little
}

The Cycadales are a group of significant global conservation concern and have the highest extinction risk of all seed plants. Understanding the synchronisation of reproductive phenology of Cycadales may be useful for conservation by enabling the targeting of pollen and seed collection from wild populations and identifying the window of fertilisation to aid in the cultivation of Cycadales. Phenological data for 11 species of Zamia were gathered from herbarium specimens. Four phenological characters were coded with monthly character states. DNA was isolated and sequenced for $26 \mathrm{~S}, C A B$, $N E E D L Y$, mat $K$ and $r b c L$, and a simultaneous phylogenetic analysis of phenology and DNA sequence data was carried out. Three major clades were recovered: a Caribbean clade, a Central American clade and a South American clade. Eight species showed statistically significant synchronisation in microsporangiate and ovulate phenological phases, indicating the time of fertilisation. Close reproductive synchronisation was consistently observed throughout the Caribbean clade (statistically significant in four of five species) but was less consistent in the Central American clade (statistically significant in one of two species) and South American clade (statistically significant in three of four species). Ultimately, phenology is shown to be a potential driver of speciation in some clades of Zamia and in others to be a potential barrier to hybridisation.

Keywords. Circular statistics, Cycadales, dioecy, phenograms. phenology, reproductive timing, Zamia.

\section{INTRODUCTION}

Shifts in the reproductive timing of plants have attracted increasing interest among researchers. For example, climate change is considered to have a significant effect on the phenological cycles and synchrony of plants, which could ultimately affect the diversity and abundance of plant species (Gordo \& Sanz, 2010; Ovaskainen et al., 2013).

The Cycadales are a group of significant global conservation concern and have the highest extinction risk of all seed plants (IUCN, 2015). Asynchronous phenological

\footnotetext{
Royal Botanic Garden Edinburgh, 20A Inverleith Row, Edinburgh EH3 5LR, Scotland, UK. E-mail for correspondence: jclugston@rbge.ac.uk

2 Montgomery Botanical Center, 11901 Old Cutler Road, Coral Gables, FL 33156-4242, USA.

3 New York Botanical Garden, 2900 Southern Boulevard, Bronx, New York, NY 10458-5126, USA.
} 
patterns can be problematic in small isolated populations, negatively affecting the fitness of these populations and threatening their survival (Schneider et al., 2002; López-Gallego, 2007; Reed et al., 2013). Understanding the reproductive phenology of plants can further our understanding of reproductive isolation mechanisms, which can, in turn, be used directly in conservation by aiding in the cultivation and propagation of ex situ collections (Gorelick \& Marler, 2012). Cycadales cannot self-pollinate, because they are dioecious and therefore require reproductive synchronisation. Dioecy in species means obligate outcrossing, and synchronisation is essential. This may be problematic in smaller populations, and exacerbated by their push-pull pollination mechanism (an odour-mediated interaction between cycads and their pollinators) that is essential for pollination to occur (Terry et al., 2005; Suinyuy et al., 2009, 2013). Therefore the phenology of Cycadales is particularly biologically significant.

Zamia L. is the largest genus in Zamiaceae, consisting of more than 70 species (Osborne et al., 2012) that are widely distributed throughout the Neotropics. Zamia inhabits rain forest, coastal swamps, deserts, beaches and epiphytic habitats. It is perhaps the most morphologically and ecologically diverse genus of the extant Cycadales (Jones, 2002). Wild populations of Zamia fairchildiana L.D.Gómez produce a flush of leaves during and after the wet season (López-Gallego \& O’Neil, 2010). In Zamia, a new flush of leaves often coincides with the production of strobili (Prado et al., 2014). Under certain environmental conditions, such as water stress, zamias have been known to abort strobili to favour the production or retention of leaves (NegrónOrtiz \& Breckon, 1989). However, plants that are in an active state of seed maturation initiate the senescence-leaves in unfavourable conditions and retain the strobili to allow the maturation of seeds (Negrón-Ortiz and Breckon, 1989).

Wild Zamia populations often consist of a large number of mature plants, yet only a small number might participate in a given reproductive event (Ornduff, 1987, 1992). Microsporangiate Zamia often produce multiple strobili within a single growing season, presumably because microsporangiate strobili require fewer resources than megasporangiate strobili (Tang, 1990). Microsporangiate strobili produced in multiples often mature at different times (Schutzman, 2004). Clark \& Clark (1987, 1988) produced one of the most detailed studies of cycad phenology, focused on Zamia skinneri Warsz. (now regarded as a synonym of Z. neurophyllidia D.W.Stev.), with observations of more than 200 individuals over a 6-year period. Clark \& Clark (1987, 1988) found that microsporangiate plants began to release pollen before receptivity of megasporangiate plants, with larger microsporangiate plants being able to shed pollen over a longer period of time; that $26 \%$ of adult plants produced megasporangiate strobili within the 6-year period; and that rates of leaf production were negatively correlated with the production of strobili, demonstrating the drain on resources that the reproductive process imposes.

Clugston et al. (in press) collected data from both wild-collected herbarium specimens and living collections of 22 species of Zamia and found significant variation in phenological patterns among species as well as between wild and cultivated plants 
of the same species. The pollination mechanism in Zamia has been well documented (Norstog et al., 1986; Tang, 1987, Norstog \& Fawcett, 1989; Vovides et al., 1993; Terry et al., 2012) and is often directly linked to the life cycle of the beetle pollinators (Curculionidae). This suggests that timing is an important factor: the dehiscence of the pollen sacs must coincide with the opening of the megasporophylls and the secretion of pollination droplets for fertilisation to occur (Donaldson, 1997; Terry et al., 2007). Some species of Zamia share the same pollinator (Blake \& Holzman, 2012) and occur within a small geographical range. In these species, asynchronous reproduction is a potential prezygotic isolation mechanism (Clugston et al., in press).

Our aim in doing this study was to provide insight into the phenology of wild Zamia by analysing reproductive phenological phases in the context of a phylogeny inferred from nuclear, plastid and mitochondrial DNA. In doing so, we assume that phenology is a heritable character (i.e. phenological synapomorphies are a result of common ancestry).

We hoped to answer a number of questions. First, are phenological data more or less consistent with phylogeny? Second, is it the microsporangiate or the megasporangiate phase that drives evolutionary changes in the phenology of Zamia? Third, is phenology a barrier to hybridisation or a driver of speciation and radiation?

\section{Materials and Methods}

\section{Phenology}

Phenological observations were obtained from herbarium specimens of known wild collections of 11 species of Zamia L., i.e. Z. acuminata Oerst. ex Dyer, Z. angustifolia Jacq., Z. erosa O.F.Cook \& G.N.Collins, Z. integrifolia L.f., Z. lecointei Ducke, Z. manicata Linden ex Regel, Z. muricata Willd., Z. neurophyllidia D.W.Stev., Z. pumila L., Z. pygmaea Sims and Z. roezlii Linden, and two outgroup taxa, Ceratozamia robusta Miq. and Microcycas calocoma (Miq.) A.DC. These observations were gathered from 25 herbaria (AAH, AAU, AHUC, B, BM, COAH, COL, CR, E, F, FTG, GH, HUA, JBSD, K, LE, MGR, MO, NY, P, PENN, SEL, U, US and VEN; herbarium codes follow Thiers et al., continuously updated). All herbarium specimens were verified against relevant floras and checklists (Vovides, 1992; Stevenson, 2004; Nicolalde-Morejón et al., 2009; Osborne et al., 2012). Specimens examined are listed in Appendix 1. Each specimen was categorised into one of the following four states: 1, closed pollen (condensed central axis, closed microsporangia with included microspores); 2, open pollen (OP; elongated central axis, dehisced microsporangia, free microspores); 3, early ovule (EO; immature megagametophyte, ovulate cone open and receptive); or 4, late ovule ( $\mathrm{LO}$; mature megagametophyte and degraded sarcotesta; seeds lacking evidence of sarcotesta were excluded). Phenological phases were recorded as days of the year and then converted to angles before analysis. Statistical analyses and visualisations were carried out using $\mathrm{R}$ framework 3.01 (R Core Team, 2013). The Circular Statistics package version 0.4-3 (Agostinelli \& Lund, 2011) was used to plot 
rose diagrams ('phenographs' sensu Griffith et al., 2012) and to calculate Wallraff test values (Wallraff, 1979).

\section{Estimation of relationships}

DNA isolation and sequencing of the large ribosomal subunit (26S; high-copy nuclear), chlorophyll a/b-binding protein $(C A B$; single-copy nuclear, chloroplast expressed), maturase $\mathrm{K}$ (matK; plastid), $N E E D L Y$ (single-copy nuclear) and the large subunit of ribulose-1,5-bisphosphate carboxylase ( $r b c L$; plastid) follow Gorelick et al. (2014). Finished sequences were aligned with MUSCLE 3.8 (Edgar, 2004). Inferred insertions or deletions were coded as binary characters using simple indel coding (Simmons \& Ochoterena, 2000), as implemented in 2matrix (Salinas \& Little, 2014). Sequences and voucher information were archived in GenBank (Appendix table 1, Appendix 2). For each species, the dates of closed microsporangia, OP, EO and LO were coded as four characters with monthly character states. The circular relationship among phenological character states was represented using a symmetrical matrix (Sankoff, 1975), with a maximum distance of 6 steps between states (e.g. a change from November to January was counted as 2 steps, not 10). A simultaneous analysis of molecular data and phenological characters was conducted using the implicit enumeration option in TNT 1.1 (Goloboff et al., 2008). Clade support was assessed using 1000 jackknife replicates (Farris et al., 1996). Each resampled matrix was searched using implicit enumeration. The strict consensus of each jackknife replicate was used to calculate the jackknife frequency of each clade in the strict consensus of the original data.

\section{Synchronisation of open pollen and early ovule phases}

The Wallraff test was used to assess the statistical significance of differences in OP and EO timing within and among species. The method of Benjamini \& Hochberg (1995) was used to correct for multiple comparisons. To visualise the synchronisation of the OP and EO phases, data from four species with the largest numbers of phenological observations (Zamia integrifolia, Z. lecointei, Z. pumila and Z. pygmaea) were plotted using the Histogram function of Microsoft Excel 2010 (Microsoft Corp.) with 20 degree categories.

\section{RESULTS \\ Phenology}

Figures 1-4 show phenographs for 11 species of Zamia and four phenological phases. Table 1 shows the total number of phenological observations, the median observation month and the interquartile range of the median observation for each species. Here, species with 10 or more phenological observations are described, because species with fewer phenological observations are more likely to result in phenological mismatch and 
TABLE 1. Phenological observations for all 11 species of Zamia, showing the total number of observations per species

\begin{tabular}{|c|c|c|c|}
\hline Species & No. of observations* & Median observation & Interquartile range \\
\hline \multicolumn{4}{|l|}{ Closed pollen } \\
\hline Z. acuminata & 10 & January & January \\
\hline Z. angustifolia & 5 & July & May to December \\
\hline Z. erosa & 2 & April & March to May \\
\hline Z. integrifolia & 16 & November & June to November \\
\hline Z. lecointei & 11 & July & April to November \\
\hline Z. manicata & 1 & February & February \\
\hline Z. muricata & 5 & July & April to August \\
\hline Z. neurophyllidia & 4 & September & August to October \\
\hline Z. pumila & 11 & January & January \\
\hline Z. pygmaea & 2 & July & April to September \\
\hline Z. roezlii & 2 & March & March \\
\hline \multicolumn{4}{|l|}{ Open pollen } \\
\hline Z. acuminata & 3 & January & January \\
\hline Z. angustifolia & 6 & May & March to May \\
\hline Z. erosa & 8 & March & February to April \\
\hline Z. integrifolia & 30 & March & February to June \\
\hline Z. lecointei & 13 & September & April to November \\
\hline Z. manicata & 5 & December & December \\
\hline Z. muricata & 5 & April & April to June \\
\hline Z. neurophyllidia & 2 & August & July to September \\
\hline Z. pumila & 30 & March & March \\
\hline Z. pygmaea & 13 & March & February to May \\
\hline Z. roezlii & 5 & February & February to March \\
\hline \multicolumn{4}{|l|}{ Early ovule } \\
\hline Z. acuminata & 4 & January & January \\
\hline Z. angustifolia & 10 & April & February to May \\
\hline Z. erosa & 8 & March & February to April \\
\hline Z. integrifolia & 55 & April & March to June \\
\hline Z. lecointei & 10 & July & May to October \\
\hline Z. manicata & 10 & March & February to April \\
\hline Z. muricata & 6 & May & April to August \\
\hline Z. neurophyllidia & 3 & August & May to October \\
\hline Z. pumila & 32 & April & March to October \\
\hline Z. pygmaea & 27 & March & March to August \\
\hline Z. roezlii & 4 & March & March \\
\hline \multicolumn{4}{|l|}{ Late ovule } \\
\hline Z. acuminata & 3 & January & January \\
\hline Z. angustifolia & 5 & June & June \\
\hline Z. erosa & 10 & February & February to June \\
\hline Z. integrifolia & 26 & May & March to July \\
\hline Z. lecointei & 11 & July & April to September \\
\hline Z. manicata & 11 & October & July to December \\
\hline Z. muricata & 20 & April & February to July \\
\hline Z. neurophyllidia & 11 & January & January to September \\
\hline Z. pumila & 36 & July & March to October \\
\hline Z. pуgтаеа & 14 & June & March to October \\
\hline Z. roezlii & 12 & March & March to June \\
\hline
\end{tabular}

*Ten or more observations are highlighted in bold. 


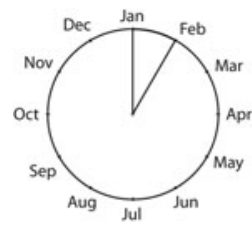

Z. acuminata $(n=10)$

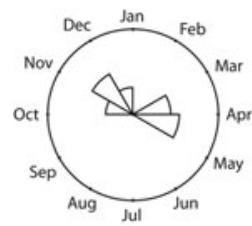

Z. lecointei $(n=11)$

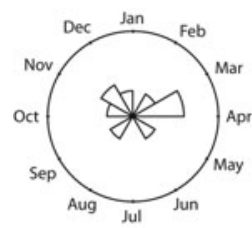

Z. pumila $(\mathrm{n}=11)$

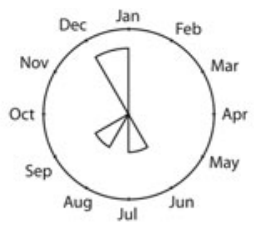

Z. angustifolia $(n=5)$

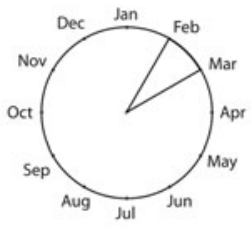

Z. manicata $(n=1)$

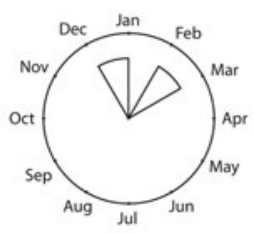

Z. pygmaea $(n=2)$

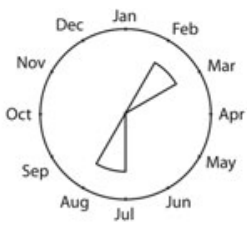

Z. erosa $(n=2)$

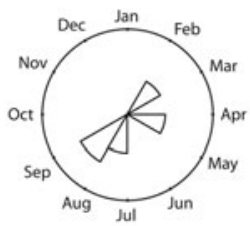

Z. muricata $(n=5)$

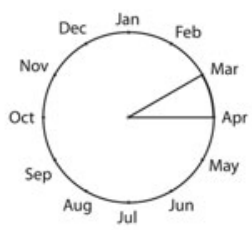

Z. roezlii $(n=2)$

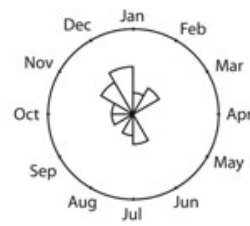

Z. integrifolia $(n=16)$

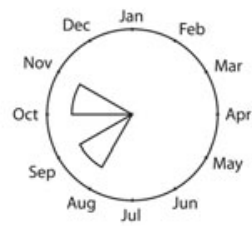

Z. neurophyllidia $(n=4)$

FIG. 1. Phenographs of the closed pollen phenological phase for data from 11 species of Zamia gathered from herbarium specimens.

less accurate results, although these species still provide insights into the phenological timing of a species.

Closed pollen. The closed pollen phase, which is defined by the pre-elongation of the central axis and the prerelease of pollen, is shown in phenographs of 11 Zamia species in Fig. 1. The corresponding phenological observation data are shown in Table 1. Zamia acuminata, Z. integrifolia, Z. lecointei and Z. pumila all have 10 or more observations (Table 1) and therefore greater statistical support. Both Zamia pumila and $Z$. integrifolia show a rather extended phenological cycle, with observations almost year round, and with the highest recorded frequencies of observations among all the phenographs. The median observations for Zamia pumila and Z. integrifolia differ from each other, however.

Open pollen. The OP phase is defined by the release of pollen and the elongation of the central axis (Table 1 and Fig. 2). Zamia integrifolia, Z. lecointei, Z. pumila and $Z$. pygmaea all have 10 or more observations, with $Z$. integrifolia having the greatest number at 30 . However, $Z$. lecointe $i$ has the greatest range of phenological observations based on its interquartile range.

Early ovule. The EO phase is defined by the point of ovulate receptivity (Table 1 and Fig. 3). Zamia angustifolia, Z. integrifolia, Z. lecointei, Z. manicata, Z. pumila and $Z$. pygmaea all have more than 10 observations, and $Z$. integrifolia has the greatest number 


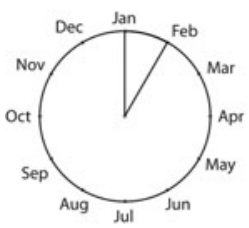

Z. acuminata $(n=3)$

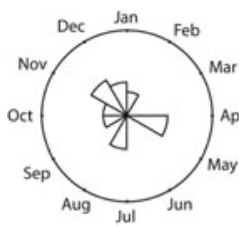

Z. lecointei $(n=13)$

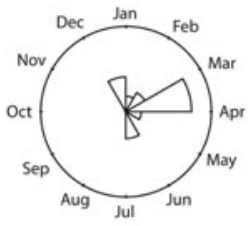

Z. pumila $(n=30)$

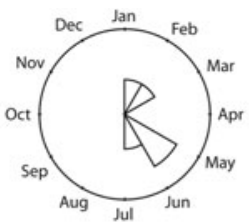

Z. angustifolia $(n=6)$

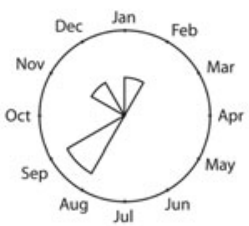

Z. manicata $(\mathrm{n}=5)$

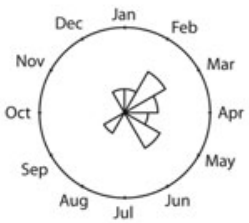

Z. pygmaea $(n=13)$

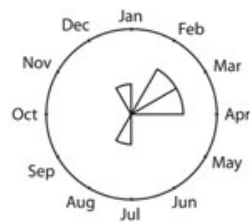

Z. erosa $(n=8)$

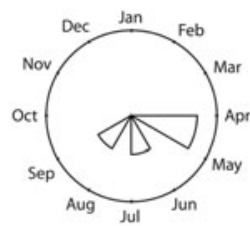

Z. muricata $(n=5)$

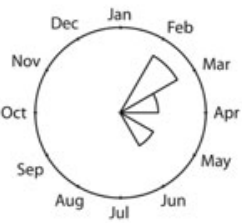

Z. roezlii $(n=5)$

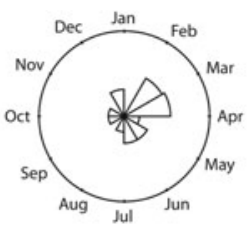

Z. integrifolia $(n=30)$

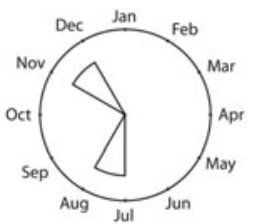

Z. neurophyllidia $(\mathrm{n}=2)$

FIG. 2. Phenographs of the open pollen phenological phase for data from 11 species of Zamia gathered from herbarium specimens.

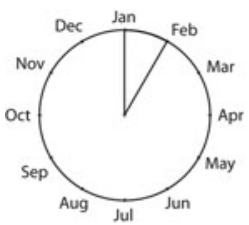

Z. acuminata $(n=4)$

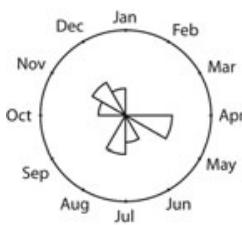

Z. lecointei $(\mathrm{n}=10)$

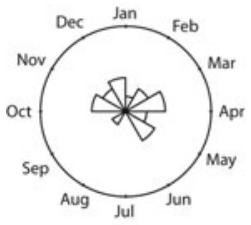

Z. pumila $(n=32)$

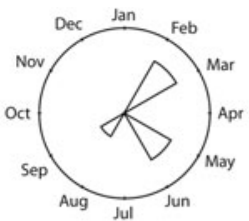

Z. angustifolia $(n=10)$

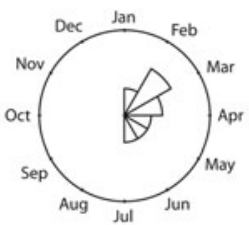

Z. manicata $(n=10)$

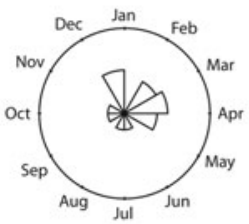

Z. pygmaea $(\mathrm{n}=27)$

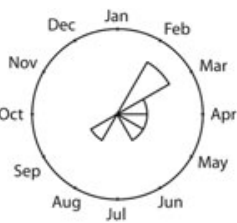

Z. erosa $(n=8)$

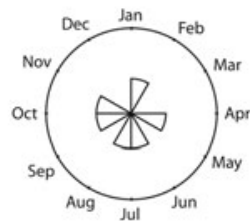

Z. muricata $(n=6)$

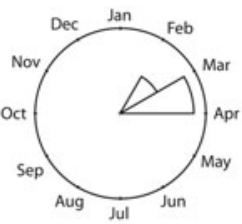

Z. roezlii $(n=4)$

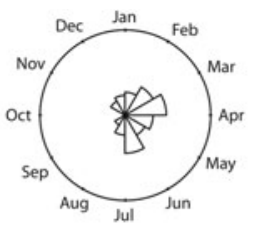

Z. integrifolia $(\mathrm{n}=55)$

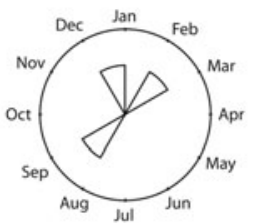

Z. neurophyllidia $(\mathrm{n}=3)$

FIG. 3. Phenographs of the early ovule phenological phase for data from 11 species of Zamia gathered from herbarium specimens. 


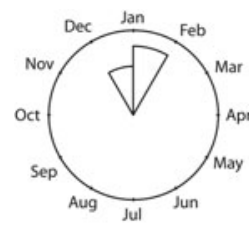

Z. acuminata $(n=3)$

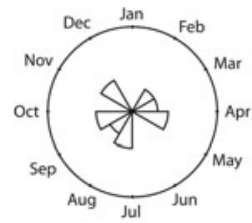

\section{Z. lecointei $(\mathrm{n}=11)$}

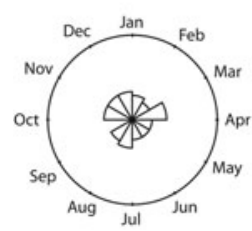

Z. pumila $(n=36)$

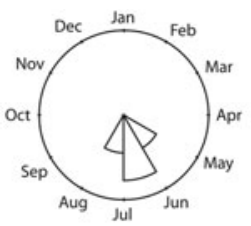

Z. angustifolia $(n=5)$

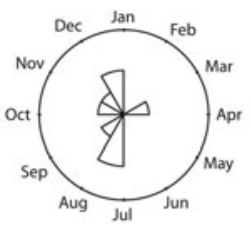

Z. manicata $(\mathrm{n}=11)$

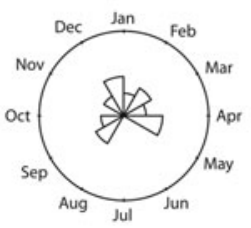

Z. pygmaea $(n=14)$

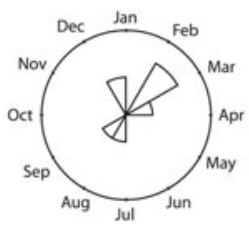

Z. erosa $(n=10)$

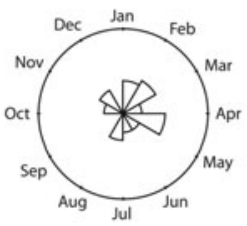

Z. muricata $(n=20)$

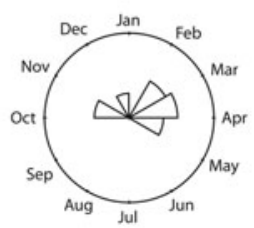

Z. roezlii $(n=12)$

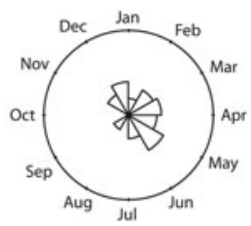

Z. integrifolia $(n=26)$

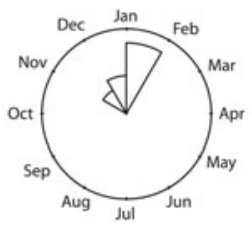

Z. neurophyllidia $(n=11)$

FIG. 4. Phenographs of the late ovule phenological phase for data from 11 species of Zamia gathered from herbarium specimens.

at 55. Zamia pumila has the greatest range of phenological observations from March to October.

Late ovule. The LO phase (Table 1 and Fig. 4) is defined by the hardening of the sclerotesta and the release of seeds. Zamia erosa, Z. integrifolia, Z. lecointei, $Z$. manicata, Z. muricata, Z. neurophyllidia, Z. pumila, Z. pygmaea and Z. roezlii all have more than 10 observations, with $Z$. pumila having the greatest number.

\section{Phylogeny}

The 180 parsimony-informative characters are unevenly distributed among the five markers: 26S, 69; matK, 45; NEEDLY, 33; rbcL, 21; and $C A B, 8$. The strict consensus of the 12 most parsimonious trees from the simultaneous analysis (Fig. 5) has three well-supported clades, with the most parsimonious trees having a consistency index of 0.850 and a retention index of 0.873 . The mean jackknife support value is $60.9 \%$. The 'Caribbean clade' has a 99\% jackknife support value and contains five species: Zamia integrifolia, Z. pumila, Z. pygmaea, Z. erosa and Z. angustifolia. The 'Central American clade' contains two species: Zamia neurophyllidia and Z. acuminata, united with a $66 \%$ jackknife support value. The 'South American clade' has an 88\% support value and contains four species: Zamia roezlii, Z. manicata, Z. muricata and Z. lecointei. 


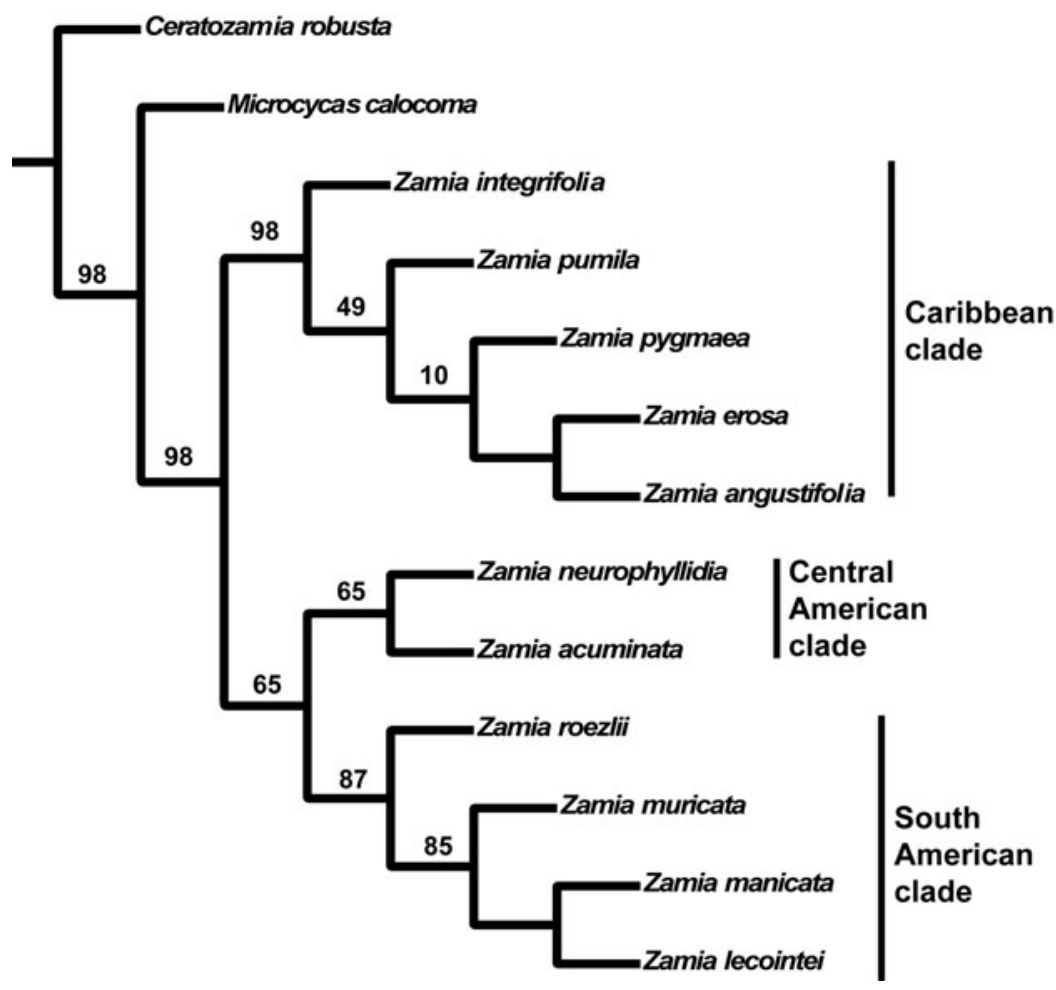

FIG. 5. Parsimony tree of Zamia generated from DNA sequence data from the large ribosomal subunit (26S; high-copy nuclear), chlorophyll a/b-binding protein (CAB; single-copy nuclear, chloroplast expressed), maturase $\mathrm{K}$ (matK; plastid), NEEDLY (single-copy nuclear) and the large subunit of ribulose-1,5-bisphosphate carboxylase ( $r b c \mathrm{~L}$; plastid). The tree is a strict consensus of 12 trees, with a consistency index of 0.850 and a retention index of 0.873 . Jackknife support values are shown at nodes with a mean group support of $60.9 \%$.

Phenological character optimisation. For discussion, a single tree from the simultaneous analysis was randomly selected from the 12 most parsimonious trees, and phenological data for closed pollen, OP, EO and LO were optimised (Sankoff, 1975) onto the nodes (Fig. 6). Fig. 6 indicates that the EO phase is 2 (February) for all species of Zamia, and there are resulting parallel shifts in OP phase to 2 on both of the diverging branches. Later, there is a change in EO phase to 4 (April) and 6 (June), and again a change in OP phase to include 4.

Caribbean clade. The Caribbean clade has a number of synapomorphies in the four phenological characters. The reconstruction indicates that there is a change in OP timing in the clade, which results in synchronisation of the OP and EO phases. Zamia erosa and $Z$. angustifolia show a further change in the observations for the LO phase during July and December. 


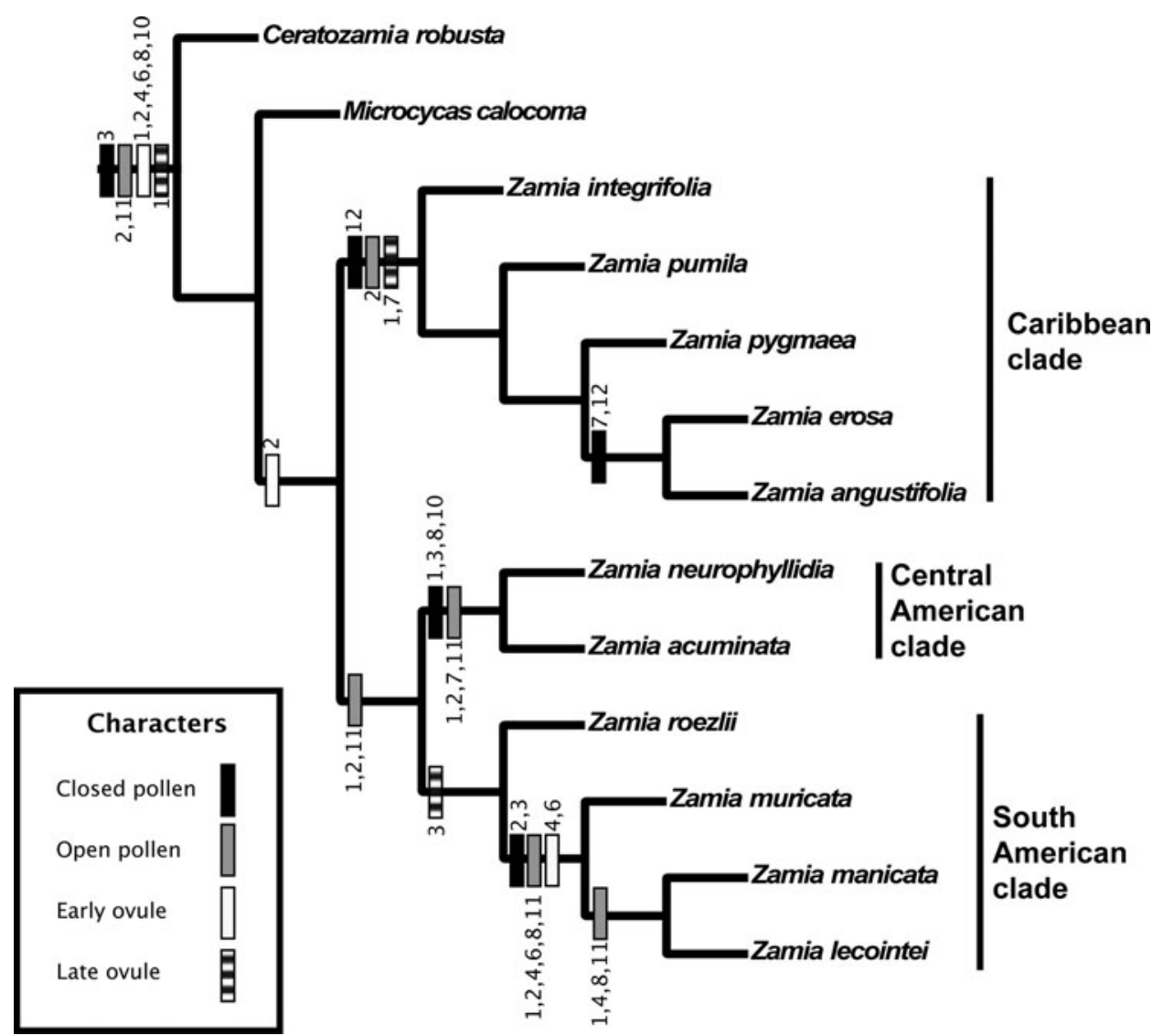

FIG. 6. Phylogenetic tree showing unambiguous synapomorphic character state changes for four phenological characters (autapomorphies are not shown). Numbers at the site of each character state change indicate month(s) of the year. All phenological characters have a consistency index of 0.850 and a retention index of 0.873 .

Central American clade. Zamia neurophyllidia and Z. acuminata are synapomorphic in $\mathrm{OP}$ and closed pollen. OP and EO phases are synchronised during February, but the OP phase is also active during January, July and November (Fig. 6).

South American clade. The South American clade has a synapomorphy in the LO phase. The Zamia muricata subclade has an increase in the OP during April, June and August, whereas $Z$. lecointei and $Z$. manicata show a slight reduction in observations during February (Fig. 6).

\section{Synchronisation}

Zamia integrifolia, Z. lecointei, Z. pumila and Z. pygmaea had the highest number of observations for the EO and OP phases of all 11 species of Zamia, with the 
four species examined in detail (Figs 7-10) being synchronised between EO and OP phases.

Table 2 shows the significance of OP and EO, whether they show asynchronisation in their phenological pattern for each species and whether the species are significantly differentiated based on phenological data. Significant $(P<0.001)$ differences were found in the timing of $\mathrm{OP}$ and $\mathrm{EO}$ in Zamia pumila $(P=0.0002)$, indicating asynchronisation in phenology.

Significant $(P<0.01)$ differences were noted between species in the timing of the OP and EO phases; Zamia acuminata differs significantly from all species, with the exception of $Z$. neurophyllidia and $Z$. roezlii. Zamia pumila is significantly different from $Z$. acuminata $(P=0.001), Z$. integrifolia $(P=0.003)$ and $Z$. lecointei $(P=0.005)$; however, no significant infraspecific differences were found.

Significant infraspecific differences $(P<0.05)$ were found in OP and EO timing for both Zamia acuminata $(P=0.02)$ and $Z$. roezlii $(P=0.02)$. Significant interspecific differences were found between a number of species: Zamia acuminata differs significantly from $Z$. erosa $(P=0.01), Z$. lecointei $(P=0.01), Z$. manicata $(P=0.01), Z$. muricata $(P$ $=0.02), Z$. neurophyllidia $(P=0.046)$ and $Z$. roezlii $(P=0.03)$. Zamia angustifolia has borderline difference from $Z$. roezlii $(P=0.051)$, which is also the case for $Z$. integrifolia $(P=0.03), Z$. manicata $(P=0.01), Z$. muricata $(P=0.01)$ and $Z$. pygmaea $(P=0.02)$, which in turn differ significantly from $Z$. roezlii. Zamia erosa differs significantly in its OP and EO timing from $Z$. angustifolia $(P=0.048), Z$. pumila $(P=0.03)$ and $Z$. roezlii $(P=0.02)$. Zamia muricata differs significantly from $Z$. angustifolia $(P=0.04)$ and $Z$. roezlii $(P=0.01)$. The OP and $\mathrm{EO}$ of $Z$. neurophyllidia differ significantly from those of $Z$. acuminata $(P=0.03)$ and $Z$. roezlii $(P=0.046)$. Zamia pumila differs significantly from $Z$. angustifolia $(P=0.01), Z$. muricata $(P=0.02)$ and $Z$. pygmaea $(P=0.02)$. Zamia roezlii differs significantly in its OP and $\mathrm{EO}$ from those of $Z$. acuminata $(P=$ $0.01), Z$. angustifolia $(P=0.04)$ and $Z$. pumila $(P=0.01)$.

\section{DISCUSSION}

\section{Strengths and weaknesses of the data}

The data were gathered from 1265 herbarium specimens providing phenological data and represent one of the largest and most complete phenological datasets available for Zamia even when other in-depth studies (e.g. Clark \& Clark, 1987; Ornduff, 1987; Clark \& Clark, 1988; López-Gallego \& O’Neil, 2010; Ornduff, 1992; and Griffith et al., 2012) are included. The OP and closed pollen can both be clearly seen on herbarium specimens because of the elongation of the central axis of the microsporangiate strobili and the release of pollen (dehisced microsporangia). In contrast, EO was particularly difficult to see in herbarium specimens, because pollen drops are not preserved in dried specimens, and for this reason the event was recorded as an immature megagametophyte phase. The LO phase was easy to confirm because of the presence of a mature megagametophyte. 
TA B LE 2. Statistical differences ( $P$ values) between the timing of open pollen and early ovule phases in Zamia species, assessed via the Wallraff test*

\begin{tabular}{|c|c|c|c|c|c|c|c|c|c|c|c|}
\hline \multirow[b]{2}{*}{ Species } & \multicolumn{5}{|c|}{ Caribbean clade } & \multicolumn{2}{|c|}{ Central American clade } & \multicolumn{4}{|c|}{ South American clade } \\
\hline & $\begin{array}{l}Z . \\
\text { angustifolia }\end{array}$ & $\begin{array}{l}Z . \\
\text { erosa }\end{array}$ & $\begin{array}{l}Z \text { Z. } \\
\text { integrifolia }\end{array}$ & $\begin{array}{l}\text { Z. } \\
\text { pumila }\end{array}$ & $\begin{array}{l}Z . \\
\text { pygmaea }\end{array}$ & $\begin{array}{l}Z \text {. } \\
\text { acuminata }\end{array}$ & $\begin{array}{l}Z . \\
\text { neurophyllidia }\end{array}$ & $\begin{array}{l}Z . \\
\text { lecointei }\end{array}$ & $\begin{array}{l}Z \text {. } \\
\text { manicata }\end{array}$ & $\begin{array}{l}Z \text {. } \\
\text { muricata }\end{array}$ & $\begin{array}{l}Z . \\
\text { roezlit }\end{array}$ \\
\hline Z. angustifolia & 0.74 & 0.80 & 0.73 & 0.15 & 0.82 & 0.008 & 1 & 0.28 & 0.83 & 0.42 & 0.051 \\
\hline Z. erosa & 0.048 & 0.29 & 0.35 & 0.03 & 0.31 & 0.005 & 0.41 & 0.050 & 0.79 & 0.12 & 0.016 \\
\hline Z. integrifolia & 0.45 & 0.91 & 0.73 & 0.09 & 0.74 & 0.001 & 0.66 & 0.08 & 0.57 & 0.25 & 0.03 \\
\hline Z. pumila & 0.015 & 0.015 & 0.003 & 0.0002 & 0.02 & 0.001 & 0.23 & 0.0002 & 0.15 & 0.02 & 0.56 \\
\hline Z. pygmaea & 0.31 & 0.94 & 0.31 & 0.06 & 0.32 & 0.003 & 0.74 & 0.11 & 0.62 & 0.22 & 0.017 \\
\hline Z. acuminata & 0.009 & 0.014 & 0.009 & 0.008 & 0.02 & 0.018 & 0.046 & 0.011 & 0.011 & 0.019 & 0.03 \\
\hline Z. neurophyllidia & 0.07 & 0.29 & 0.83 & 1 & 0.67 & 0.03 & 0.55 & 1 & 0.19 & 1 & 0.046 \\
\hline Z. lecointei & 1 & 0.51 & 0.23 & 0.92 & 0.55 & 0.003 & 0.64 & 0.29 & 0.21 & 0.73 & 0.017 \\
\hline Z. manicata & 0.38 & 0.77 & 0.88 & 0.50 & 0.78 & 0.009 & 0.45 & 0.33 & 0.17 & 0.46 & 0.011 \\
\hline Z. muricata & 0.04 & 0.77 & 0.58 & 0.23 & 0.94 & 0.009 & 0.88 & 0.18 & 0.46 & 0.20 & 0.011 \\
\hline Z. roezlii & 0.04 & 0.14 & 0.19 & 0.011 & 0.17 & 0.010 & 0.65 & 0.07 & 0.27 & 0.14 & 0.02 \\
\hline
\end{tabular}

${ }^{*}$ Significant differences (shown in bold) indicate statistically significant asynchronous event timing. 


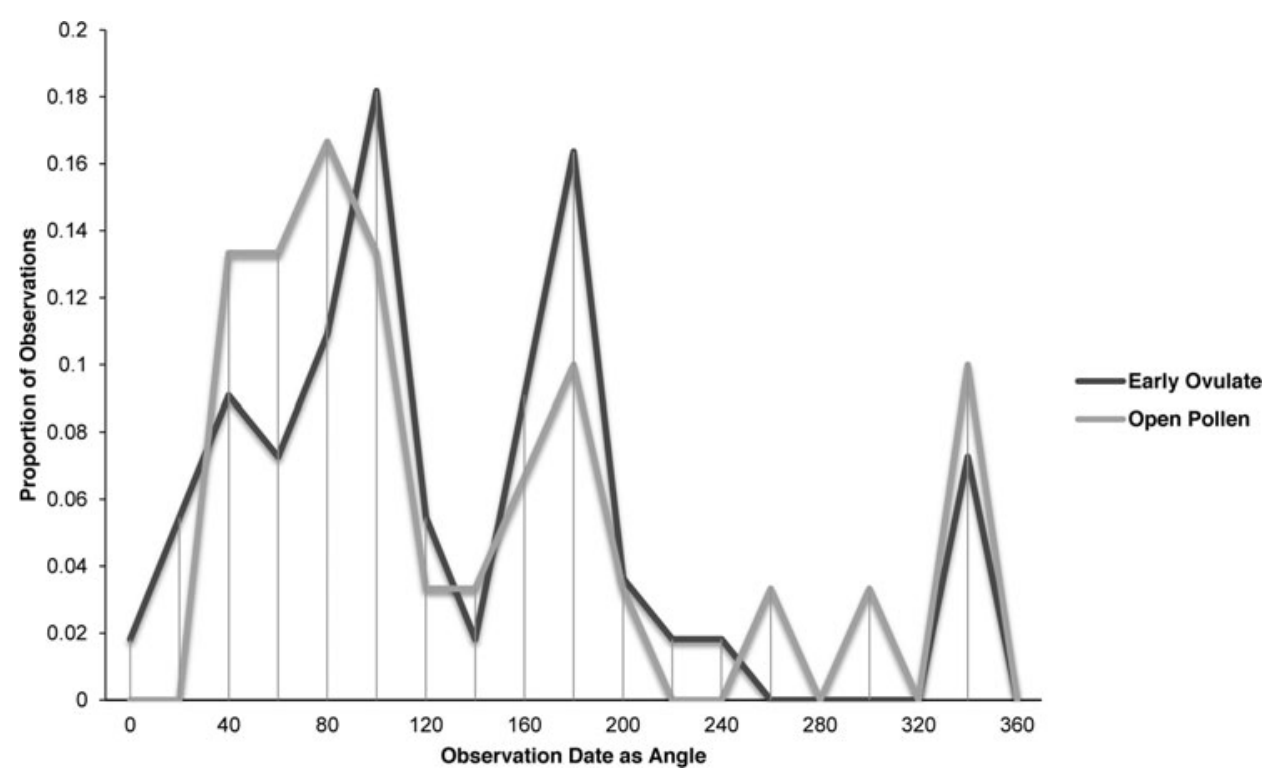

FIG. 7. Zamia integrifolia: proportion of phenological observations of cones at the open pollen and early ovule phases during the year.

\section{Importance of synchronisation of open pollen and early ovule phases}

Synchronisation between OP and EO phases is clearly manifested in Zamia integrifolia (Fig. 7), Z. lecointei (Fig. 8), Z. pumila (Fig. 9) and Z. pygmaea (Fig. 10). This indicates that data gathered from herbarium specimens can be used to understand synchronisation of the EO and OP phases in closely related species with little morphological differentiation, and can therefore also be used as an aid for species classification. Ultimately, these data provide insights into whether phenology is a barrier to hybridisation or a driver in the process of speciation. In fact, the phenological data show distinctive peaks in both OP and EO synchronisation, which indicate the window of fertilisation, because an asynchronous pattern would result in phenological mismatches that would prevent fertilisation in a species. There are similarities in the phenology of Zamia species that reside in the same clade, meaning that they would be more likely to hybridise if they occur in the same area. Species in the Caribbean clade share similarities in their geographical ranges, occurring in Florida, the Bahamas and several islands in the Greater Antilles (Osborne et al., 2012), and in some cases also share pollinators (Eckenwalder, 1980). This could allow for hybridisation within the Caribbean clade, providing there is no constraint in geography with the pollinator. This indicates that, in the Caribbean clade, phenology could be acting as a driver for speciation through the hybridisation of closely related species. In contrast, species in the Central and South American clades show lower levels of synchronisation within the clades. However, there is little to no reproductive intraspecific synchronisation 


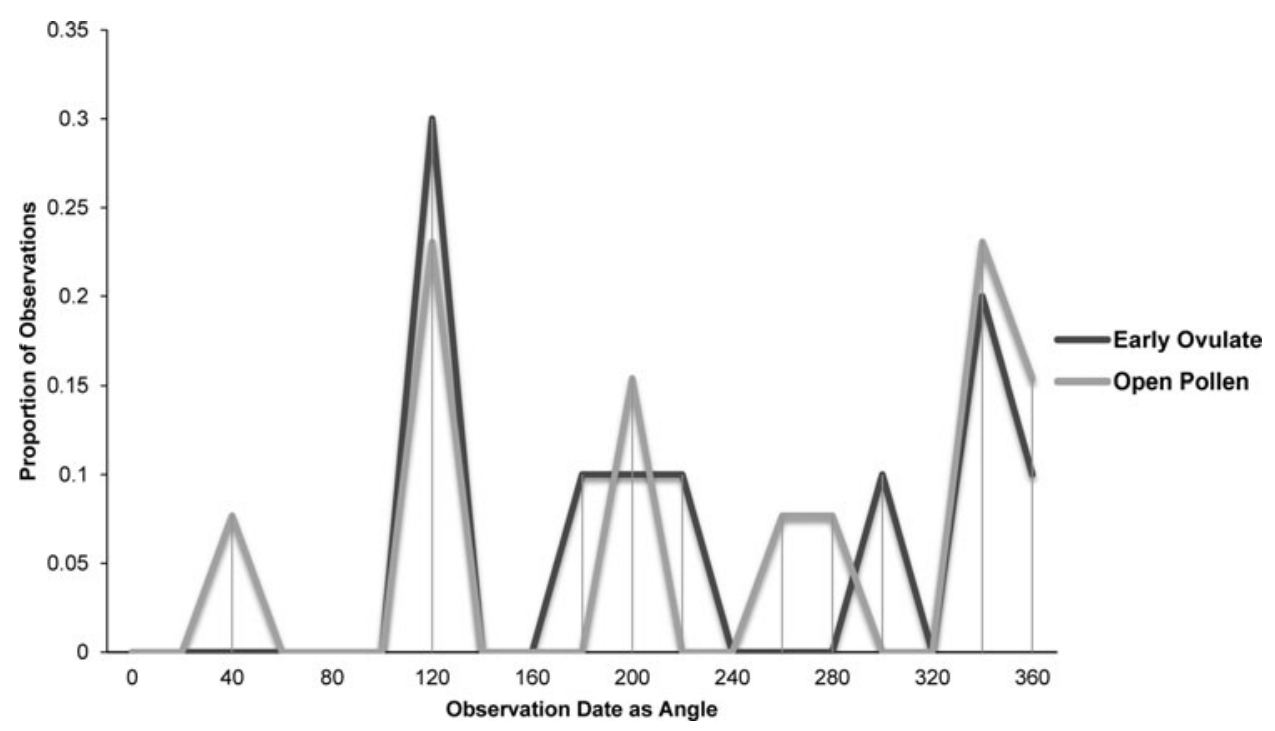

FIG. 8. Zamia lecointei: proportion of phenological observations of cones at the open pollen and early ovule phases during the year.

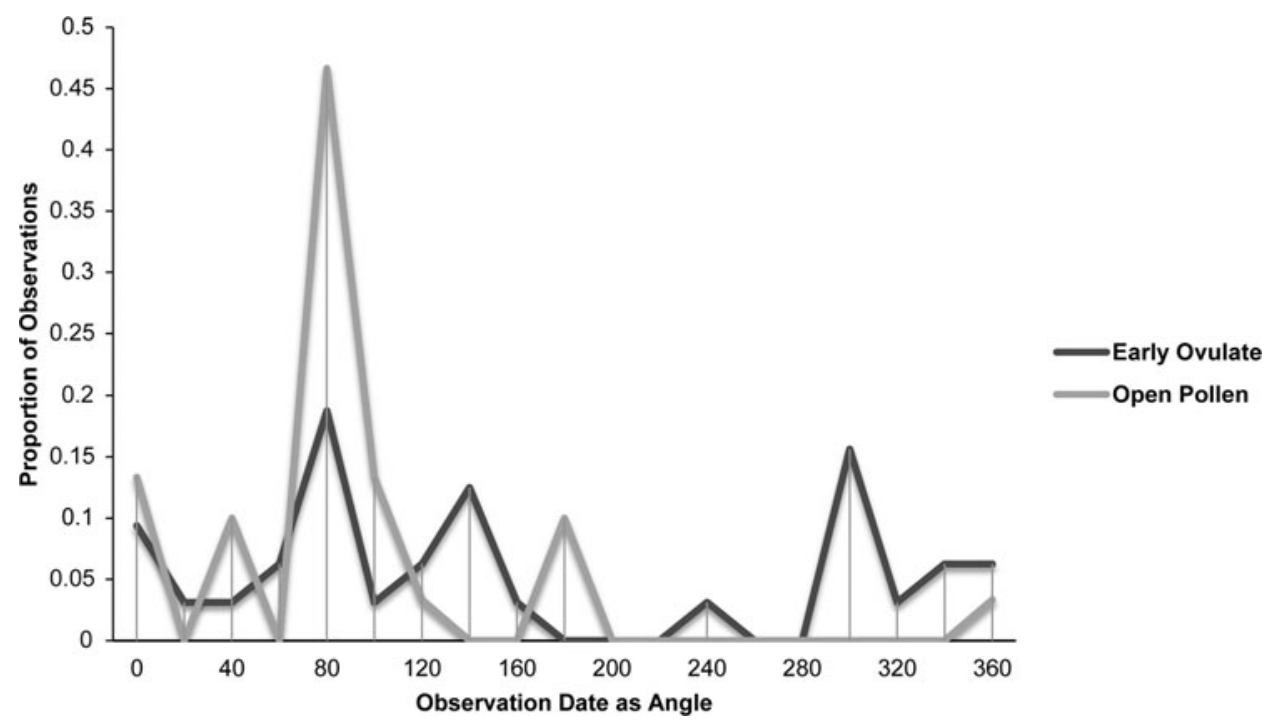

FIG. 9. Zamia pumila: proportion of phenological observations of cones at the open pollen and early ovule phases during the year.

in these two clades, and species have a greater level of geographical differentiation (Osborne et al., 2012; Clugston et al., in press). This indicates that within the Central and South American clades there are lower chances of interspecific hybridisation 


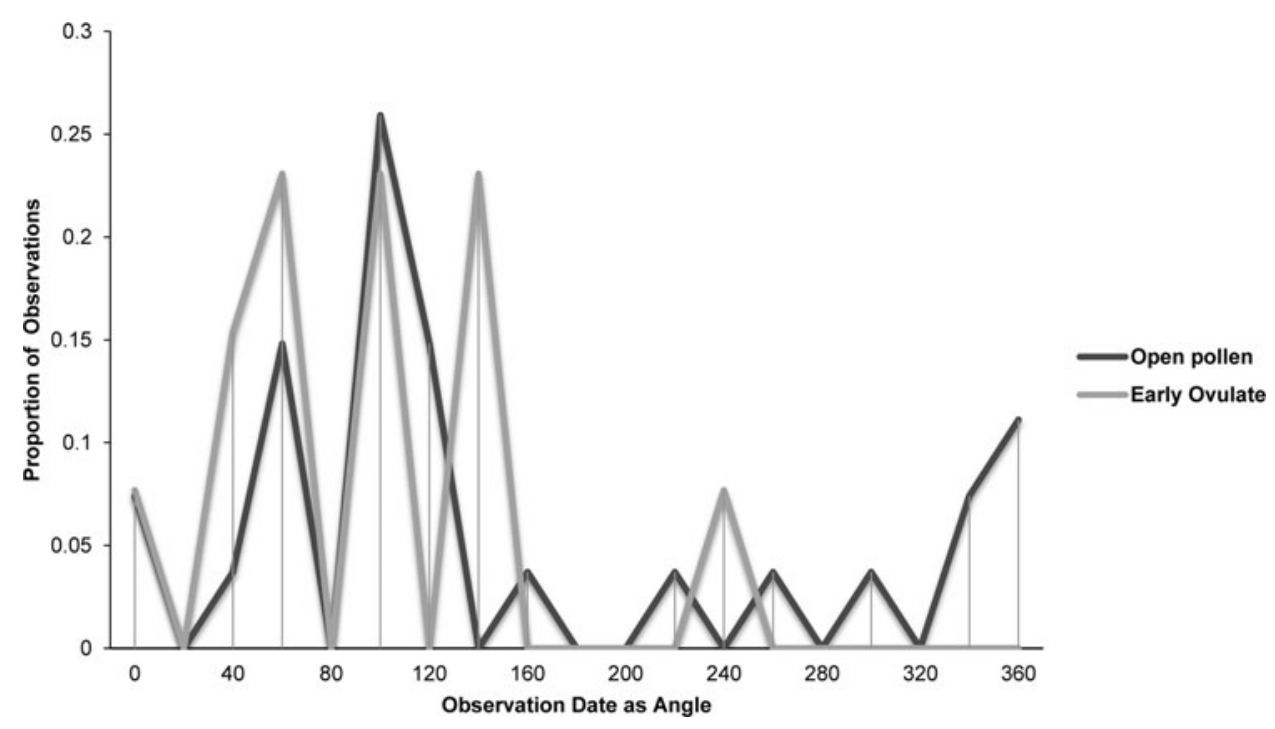

FIG. 10. Zamia pygmaea: proportion of phenological observations of cones at the open pollen and early ovule phases during the year.

events occurring, indicating that both phenology and geography act as barriers to hybridisation.

Zamia acuminata, $Z$. pumila and $Z$. roezlii show significant interspecific differentiation between the OP and EO phases. This can be explained in both Zamia acuminata and $Z$. roezlii, because both species have five or fewer phenological observations of OP and EO. Fewer phenological observations of both species provide less statistical support and a higher chance of phenological mismatches. With a greater number of phenological observations, Zamia acuminata and $Z$. roezlii should show less statistical significance between the OP and EO and a lower chance of phenological mismatches. However, Zamia pumila has more than 30 observations of both OP and EO, meaning greater statistical support. The question remains as to why there is significant differentiation between the OP and EO phases in this species. Zamia pumila, as currently circumscribed (Osborne et al., 2012), has a wide distribution, including Cuba, Hispaniola (Dominican Republic only) and Puerto Rico, each with similar climatic conditions. The disjunct distribution of the species on three separate islands could also indicate potential differences in the pollinators and seasonality of strobilus production times, indicating a high chance of phenological mismatch in disjunct populations.

\section{Phenology and climate}

Zamia lecointei and Z. pumila share the same overlap between the OP and EO at about 1 month, leaving only a small window for fertilisation to occur. The phenological 
patterns of many plants species are strongly correlated with environmental factors such as precipitation, temperature and carbon dioxide levels (Forkner et al., 2008). Therefore changes in climate may influence phenological patterns of Zamia, resulting in a phenological cycle that has become differentiated from that of the pollinators. This would directly affect the period of fertilisation and thereby population fitness and resilience. Reed et al. (2013) found that phenology patterns of plants can be shifted in response to climate change. This shift in phenology often results in asynchronous patterns that may ultimately affect plant-pollinator interactions (Willmer, 2012). The often short period for pollination to occur in some species of Zamia increases the likelihood that they will develop asynchronous phenological cycles as a result of environmental changes. Cycads often have species-specific pollinators that are directly involved in their push-pull pollination system (Suinyuy et al., 2009, 2013). The pollination system of cycads requires perfect synchronisation between the EO and OP, and depends heavily on the push-pull system and environmental factors, which could be affected by the loss of a pollinator or changes in environmental conditions such as precipitation or drought. Zamia pumila has a more extended phenological cycle and has highly significant differences in its OP and EO phases that are more prone to phenological mismatch.

\section{Seasonal environmental changes and mast strobilus production}

Seasonal and environmental changes influence the cyclical production of strobili in cycads (Marler \& Niklas, 2011). Mast strobilus production, in which many individuals in a population simultaneously produce strobili, is reported in Macrozamia Miq. (Ballardie \& Whelan, 1986), Encephalartos Lehm. (Donaldson, 1993, Suinyuy et al., 2009) and Zamia (Negrón-Ortiz \& Breckon, 1989). Tang (1990) found that, after fire, $87 \%$ of mature Zamia pumila plants participated in a mast seeding event. The effects of fire and mast seed production have also been recorded in Encephalartos (Grobbelaar et al., 1989), Dioon Lindl. (Vovides, 1990) and Macrozamia (Grove et al., 1980).

\section{Phenology and phylogeny}

Eckenwalder (1980) observed many morphological similarities among the species in the Caribbean clade, which greatly influenced his classification of the genus, implying that the Integrifolia group is a single morphologically plastic species. However, more recent studies have indicated that the Integrifolia group can be split into the nine or more distinct species that are currently recognised in the clade (Stevenson, 1987; Meerow et al., 2012). Zamia integrifolia and Z. pumila have the greatest number of phenological observations in our dataset, and both species have a large geographical range. Therefore variability in their phenological patterns is unsurprising given the many different environments across their ranges. The EO of both species is scattered throughout the year, indicating a long cycle of receptivity, but the OP has a much more defined cycle, which indicates a shorter window for fertilisation to occur. 
Species of Zamia in the Caribbean clade share a close molecular relationship, which is further supported by phenological similarities and synchronisation of OP and EO phases, with the exception of Z. angustifolia. When compared with other members of the Caribbean clade, Zamia angustifolia has a limited geographical range, with populations in the Bahamas and Cuba (Calonje et al., 2013). Zamia angustifolia populations are disjunct from the other species (Z. integrifolia and $Z$. pumila) that occur in the same regions. Zamia angustifolia is also phenologically isolated from closely related species; this further suggests that there is little genetic exchange between $Z$. angustifolia and the other species of Zamia. However, perfect phenological synchronisation was recently noted between Zamia angustifolia and Z. integrifolia in the Bahamas, where microsporangiate strobili were found releasing pollen at the same time as mature seeds were found on megasporangiate strobili (M. Calonje, Montgomery Botanical Center, pers. comm., 30 June 2015).

The phenological patterns of the South American clade show higher levels of differentiation among characters, perhaps because of the much lower availability of material. However, species within the South American clade are in close geographical proximity and resolve in the same clade, indicating that phenology is consistent with the molecular data. The members of the South American clade share few similarities in their phenology. This close geographical proximity indicates that a number of environmental conditions and triggers (e.g. day length) may be shared among species, whereas others (e.g. precipitation) may be variable (Clugston et al., in press); this indicates that strobilus production may be triggered by different environmental conditions, which differentiate the species phenologically. There are few similarities in the OP timing of Zamia manicata, Z. muricata and Z. roezlii. This segregates the month when pollen release occurs for each species, thereby limiting cross-fertilisation.

Species in the Caribbean clade show little variation in their phenological patterns and have a closely synchronised relationship between OP and EO phases. The synchronisation of phenological characters in closely related species is consistent with our assumption that phenology is inherited in this group. There is a distinct relationship between phylogeny and phenology in both the Caribbean clade and the South American clade, which further supports a close relationship between species in the two clades. The consistency index $(0.850)$ of the most parsimonious trees confirms that there is a strong relationship between phenology and phylogeny in Zamia. This indicates that species that have a close genetic relationship also share similarities in their phenology.

\section{Directions for further research}

Using statistical approaches to build on the earlier cycad phenology work of Clark \& Clark $(1987,1988)$ and Ornduff $(1987,1992)$ is an effective means to understand phenological patterns in Zamia and other members of the Cycadales (Griffith et al., 2012; Clugston et al., in press). One question that still remains to be answered is how factors such as human-mediated habitat fragmentation and habitat loss affect cycad 
phenology. Climatic factors have been shown to affect phenological patterns in other plant groups (Walther et al., 2002; Thuiller et al., 2005; Forkner et al., 2008; Reed et al., 2013), but the effects that climate change may have on the phenological cycles of cycads are still largely unknown.

Our aim in doing this study was to provide insight into the phenology of wild Zamia by analysing reproductive phenological phases in the context of a phylogeny inferred from molecular data. We have shown that phenological data are consistent with phylogeny, and that the megasporangiate phase acts as a potential driver of evolutionary changes in the phenology of Zamia. Phenology is a potential driver of speciation in some clades of Zamia, whereas in others it is a potential barrier to hybridisation. To fully understand the phenological cycles of the Cycadales growing in the wild, further studies need to be completed into other genera of cycads using wild collected herbarium specimens and wild populations. Gaining insights into the phenology of cycads could provide a greater understanding of the relationships among closely related taxa. Phenological data can also be used to provide important insights into the cultivation of ex situ conservation collections of Zamia and other genera of Cycadales, by enabling better understanding of the timing of strobilus production and period of receptivity for the EO phase. This would guide targeted pollen collection and assisted pollination during that period. Understanding reproductive biology in this way can help with ex situ cycad conservation collections, which play a fundamental role in conservation by holding genetic reserves of wild populations (Calonje et al., 2011). Furthermore, this study describes a model that could be applied to other plant groups and further shows the value of wild-collected herbarium specimens in understanding plant phenology.

\section{ACKNOWLEDGEMENTS}

The authors thank the Kelly Foundation for their support and funding through the Kelly Botanical Research Fellowship, Lindsey Patterson of the University of Edinburgh for support with statistical analysis, the Willi Hennig Society for a licence to use TNT and Brett Jestrow for use of the specimens at Fairchild Tropical Garden. The following herbaria are also acknowledged: AAH, AAU, AHUC, B, BM, COAH, COL, CR, E, F, FTG, GH, HUA, JBSD, K, LE, MGR, MO, NY, P, PENN, SEL, U, US and VEN (whose specimens were accessed through NY).

\section{REFERENCES}

Agostinelli, C. \& Lund, U. (2011). R Package 'Circular': Circular Statistics, version 0.4-3. In: Department of Environmental Sciences, Informatics and Statistics, Ca' Foscari University, Venice, Italy. UL: Department of Statistics, California Polytechnic State University, San Luis Obispo, California, USA.

Balla Rdie, R. T. \& Whelan, R. J. (1986). Masting, seed dispersal and seed predation in the cycad Macrozamia communis. Acta Oecol. 70(1): 100-105. 
Benjamini, Y. \& Hochierg, Y. (1995). Controlling the false discovery rate: a practical and powerful approach to multiple testing. J. R. Statist. Soc. B 57(1): 289-300.

Blake, A. S. T. \& Holzman, G. (2012). A new Zamia species from the Panama Canal area. Bot. Rev. 78(4): 335-344.

Calonje, M., Kay, J. \& Griffith, P. M. (2011). Propagation of cycad collections from seed: applied reproductive biology for conservation. Sibbaldia 9: 77-96.

Calonje, M., Meerow, A. W., Knowles, L., Knowles, D., Griffith, M. P., NAKAMura, K. \& Francisco-Ortega, J. (2013). Cycad biodiversity in the Bahamas Archipelago and conservation genetics of the threatened Zamia lucayana (Zamiaceae). Oryx 47(2): 190-198.

ClaR K, D. A. \& CLARK, D. B. (1987). Temporal and environmental patterns of reproduction in Zamia skinneri, a tropical rain forest cycad. J. Ecol. 75(1): 135-149.

CLARK, D. B. \& CLARK, D. A. (1988). Leaf production and the cost of reproduction in the Neotropical rain forest cycad, Zamia skinneri. J. Ecol. 76(4): 1153-1163.

Clugston, J. A. R., Griffith, P. M., Calonje, M. A., Husby, C. E., Kenicer, G. J., Little, D. P. \& Stevenson, D. W. (in press). Reproductive phenology of Zamia L. - a comparison between wild cycads and their cultivated counterparts. In: Proceedings of the 9th International Conference on Cycad Biology, 1-7 December 2011, Shenzhen, China.

Donaldson, J. S. (1993). Mast-seeding in the cycad genus Encephalartos: a test of the predator satiation hypothesis. Acta. Oecol. 94(2): 262-271.

Donaldson, J. S. (1997). Is there a floral parasite mutualism in cycad pollination? The pollination biology of Encephalartos villosus (Zamiaceae). Amer. J. Bot. 84(10): 1398-1406.

ECKenwalder, J. E. (1980). Dispersal of the West Indian cycad, Zamia pumila L. Biotropica 12(1): 79-80.

EDGAR, R. C. (2004). MUSCLE: a multiple sequence alignment method with reduced time and space complexity. BMC Bioinformatics 5: 113. 19.

Farris, J., Albert, V., Kallersjö, M., Lipscomb, D. \& Kluge, A. (1996). Parsimony jackknifing outperforms neighbor-joining. Cladistics 12(2): 99-124.

Forkner, R. E., Marquis, R. J., Lill, J. T. \& Le Corff, J. (2008). Timing is everything? Phenological synchrony and population variability in leaf-chewing herbivores of Quercus. Ecol. Entomol. 33(2): 276-285.

Goloboff, P. A., FAR Ris, J. S. \& Nixon, K. C. (2008). TNT, a free program for phylogenetic analysis. Cladistics 24(5): 774-786.

GOR D o, O. \& S A N Z, J. J. (2010). Impact of climate change on plant phenology in Mediterranean ecosystems. Global Change Biol. 16(3): 1082-1106.

GORELICK, R. \& MARLER, T. E. (2012). Evolutionary developmental biology in cycad phenology. Commun. Integr. Biol. 5(3): 272-274.

Gorelick, R., Fraser, D., Zonneveld, B. J. M. \& Little, D. P. (2014). Cycad (Cycadales) chromosome numbers are not correlated with genome size. Int. J. Pl. Sci. 175(9):986-997.

Griffith, M. P., Calonje, M. A., Stevenson, D. W., Husby, C. E. \& Little, D. P. (2012). Time, place, and relationships: cycad phenology in a phylogenetic and biogeographic context. Mem. New York Bot. Gard. 106: 59-81.

Grobbela ar, N., Meyer, J. \& Burchmore, J. (1989). Coning and sex ratio of Encephalartos transvenosus at the Modjadji Nature Reserve. S. African J. Bot. 55(1): $79-82$.

Grove, T.S., O'Connell, A.M. \& MalajCzuk, N. (1980). Effects of fire on the growth, nutrient content and rate of nitrogen fixation of the cycad Macrozamia riedlei. Austral. J. Bot. 28(3): 271. 
I UCN (2015). Summary statistics, Figure 3. In: The IUCN Red List of Threatened Species, version 2015-3. Online. Available: http://www.iucnredlist.org/about/summary-statistics (accessed 13 May 2015).

Jones, D. L. (2002). Cycads of the World. Washington, District of Columbia: Smithsonian Institution Press.

Ló PEZ-GALLEGo, C. (2007). Effects of habitat degradation on the evolutionary dynamics of populations in a rainforest cycad (Gymnospermae). Ph.D. thesis, University of New Orleans. Paper 555. Online. Available: http://scholarworks.uno.edu/td/555.

López-GAlLEGo, C. \& O’ NeIL, P. (2010). Life-history variation following habitat degradation associated with differing fine-scale spatial genetic structure in a rainforest cycad. Popul. Ecol. 52(1): 191-201.

Marler, T. E. \& Niklas, K. J. (2011). Reproductive effort and success of Cycas micronesica K.D. Hill are affected by habitat. Int. J. Pl. Sci. 172(5): 700-706.

Meerow, A. W., Francisco-Ortega, J., Colonje, M., Griffith, M. P., Ayala-Silva, T., Stevenson, D. W. \& Na Kamura, K. (2012). Zamia (Cycadales: Zamiaceae) on Puerto Rico: asymmetric genetic differentiation and the hypothesis of multiple introductions. Amer. J. Bot. 99(11): 1828-1839.

Negrón-Ortiz, V. \& Breckon, G. J. (1989). Population structure in Zamia debilis (Zamiaceae). I. Size classes, leaf phenology, and leaf turnover. Amer. J. Bot. 76(6): 891-900.

Nicolalde-Morejón, F., Vovides, A. P. \& Stevenson, D. W. (2009). Taxonomic revision of Zamia in mega-Mexico. Brittonia 61(4): 301-335.

Norstog, K. J. \& Fawcett, P. K. S. (1989). Insect-cycad symbiosis and its relation to the pollination of Zamia furfuracea (Zamiaceae) by Rhopalotria mollis (Circulionidae). Amer. J. Bot. 76(9): 1380-1394.

Norstog, K. J., Stevenson, D. W. \& Niklas, K. J. (1986). The role of beetles in the pollination of Zamia furfuracea L. fil. (Zamiaceae). Biotropica 18(4): 300-306.

ORNDUFF, R. (1987). Sex ratios and coning frequency of the cycad Zamia pumila L. (Zamiaceae) in the Dominican Republic. Biotropica 19(4): 361-364.

OR NDUFF, R . (1992). Features of coning and foliar phenology, size classes, and insect associates of Cycas armstrongii (Cycadaceae) in the Northern Territory, Australia. Bull. Torrey Bot. Club 119(1): 39-43.

Osborne, R., Calonje, M. A., Hill, K. D., Stanberg, L. \& Stevenson, D. W. (2012). Zamia. In: Dut ting, M. K. (ed.) The World List of Cycads, pp. 480-508. Bronx, New York: New York Botanical Garden Press.

Ovaskainen, O., Skorokhodova, S., Yakovleva, M., Sukhov, A., Kutenkov, A., Kutenkova, N., Shcherbakov, A., Meyke, E. \& del Mar Delgado, M. (2013). Community-level phenological response to climate change. Proc. Natl. Acad. Sci. U.S.A. 110(33): 13434-13439.

Prado, A., Sierra, A., Windsor, D. \& Bede, J. C. (2014). Leaf traits and herbivory levels in a tropical gymnosperm, Zamia stevensonii (Zamiaceae). Amer. J. Bot. 101(3): 437-447.

R Core Team (2013). R: a Language and Environment for Statistical Computing, version 3.0.1. Vienna, Austria: R Foundation for Statistical Computing.

Reed, T. E., Jenouvrier, S. \& Visser, M. E. (2013). Phenological mismatch strongly affects individual fitness but not population demography in a woodland passerine. J. Anim. Ecol. 82(1): 131-144.

Salinas, N. R . \& Little, D. P. (2014). 2matrix: a utility for indel coding and phylogenetic matrix concatenation. Appl. Pl. Sci. Jan 2(1): apps.1300083.

S A N KOFf, D. (1975). Minimal mutation trees of sequences. SIAM J. Appl. Math. 28(1): 35-42. 
Schneider, D., Wink, M., Sporer, F. \& Lounibos, P. (2002). Cycads: their evolution, toxins, herbivores and insect pollinators. Naturwissenschaften 89(7): 281-294.

Schut Zman, B. (2004). Systematics of Meso-American Zamia (Zamiaceae). In: Walters, T. \& Osborne, R. (eds) Cycad Classification: Concepts and Recommendations, pp. 159-172. Wallingford: CABI Publishing.

Simmons, M. P. \& OснотеREnA, H. (2000). Effects of gap characters on sequence-based phylogenetic analyses. Syst. Biol. 49(2): 369-381.

Stevenson, D. (1987). Comments on character distribution, taxonomy and nomenclature of the genus Zamia L. in the West Indies and Mexico. Encephalartos 9: 3-7.

Stevenson, D. W. (2004). Cycads of Colombia. Bot. Rev. 70(2): 194-234.

Suinyuy, T. N., Donaldson, J. S. \& Johnson, S. D. (2009). Insect pollination in the African cycad Encephalartos friderici-guilielmi Lehm. S. African J. Bot. 75(4): $682-688$.

Suinyuy, T. N., Donaldson, J. S. \& Johnson, S. D. (2013). Patterns of odour emission, thermogenesis and pollinator activity in cones of an African cycad: what mechanisms apply? Ann. Bot. 112(5): 891-902.

TANG, W. (1987). Insect pollination in the cycad Zamia pumila (Zamiaceae). Amer. J. Bot. 74(1): 90-99.

TANG, W. (1990). Reproduction in the cycad Zamia pumila in a fire-climax habitat: an eight-year study. Bull. Torrey Bot. Club 117(4): 368-374.

Terry, L. I., Gimme, H. W., Donaldson, J. S., Snow, E., Forster, P. I. \& Machin, P. J. (2005). Pollination of Australian Macrozamia cycads (Zamiaceae): effectiveness and behavior of specialist vectors in a dependent mutualism. Amer. J. Bot. 92(6): 931-940.

Terry, I., Walter, G. H., Moore, C., Roemer, R. \& Hull, C. (2007). Odor-mediated push-pull pollination in cycads. Science 318(5847): 70.

Terry, I., Tang, W., Marler, T. E., Stevenson, D. W., Osborne, R. \& Taylor BlAKE, A. S. (2012). Pollination systems of island cycads: predictions based on island biogeography. In: Proceedings of Cycad 2008, the 8th International Conference on Cycad Biology, 13-15 January 2008, Panama City, Panama, pp. 102-132. Bronx, New York: New York Botanical Garden Press.

Thiers, B. (continuously updated). Index Herbariorum: a Global Directory of Public Herbaria and Associated Staff. New York Botanical Garden's Virtual Herbarium. Online. Available: http://sweetgum.nybg.org/ih/

Thuiller, W., Lavorel, S., Araújo, M. B., Sykes, M. T. \& Prentice, I. C. (2005). Climate change threats to plant diversity in Europe. Proc. Natl. Acad. Sci. U.S.A. 102(23): 8245-8250.

Vovides, A. P. (1990). Spatial distribution, survival, and fecundity of Dioon edule (Zamiaceae) in a tropical deciduous forest in Veracruz, Mexico, with notes on its habitat. Amer. J. Bot. 77(12): 1532.

Vovides, A. P. (1992). The Cycads of Veracruz, Mexico. Norfolk, Virginia: El Eco de Virginia Bilingual Publishers.

Vovides, A. P., Norstog, K. J., Fawcett, P. K., Duncan, M. W., Nash, R. J. \& Molsen, D. V. (1993). Histological changes during maturation in male and female cones of the cycad Zamia furfuracea and their significance in relation to pollination biology. Bot. J. Linn. Soc. 111(2): 241-252.

WallrafF, H. G. (1979). Goal-oriented and compass-oriented movements of displaced homing pigeons after confinement in differentially shielded aviaries. Behav. Ecol. Sociobiol. 5(2): 201-225. 
Walther, G. R., Post, E., Convey, P., Menzel, A., Parmesan, C., Beebee, T. J. \& BAIR LEIN, F. (2002). Ecological responses to recent climate change. Nature 416(6879): 389-395.

Willmer, P. (2012). Ecology: pollinator-plant synchrony tested by climate change. Curr. Biol. 22(4): 131-132.

Received 3 July 2015; accepted for publication 7 July 2016

\section{APPENDIX 1}

Details of the herbarium specimens of the 11 Zamia species examined in this study

\section{Zamia acuminata Oerst. ex Dyer}

Stevenson \& Valdespinos 1147 (FTG), Stevenson 1147 (K \& NY, 1989) and Stevenson DOL31757 (NY), DOL31758 (NY), DOL31759 (NY), DOL31761 (NY), DOL31762 (NY), DOL31767 (NY), DOL31767 (NY), DOL31783 (NY).

\section{Zamia angustifolia Jacq.}

Britton \& Millspaugh 5418 (NY, 1907), Britton 408 (NY, 1905), Bro. Leon 18095 (GH, 1938), Correll et al. 42577 (FTG, 1974), Correll \& Kral 42979 (FTG, 1974), Correll \& Evans 43998 (FTG, 1974), Correll \& Hill 45240 (NY, 1975), Carabia 14003 (B \& NY, 1939), Garcia 1403 (NY, 1939), Gleuient 209 (NY, 1920), Lopéz 2970 (US, 1959), Pollard \& Palmer 382 (US, NY, MO \& GH, 1902), Norstog 730 (FTG, 1972), Proctor 36937 (FTG, 1977), Wright 597 (MO \& P, GH, LE, PENN, 1856).

\section{Zamia erosa O.F.Cook \& G.N.Collins}

Axelrod 3393 (NY, 1991), Britton \& Hollick 2042 (NY, 1908), Britton et al. 8903 (NY, 1925), Carabia 4102 (F,1940), Proctor 31556 (GH, 1970), Read and Drummond 76-640 (FTG, 1976), Shafer 1402 (NY, 1909), Simson 3816 (NY, 1966), Turnbull 14, 15, 16, 18, 19, 20, 21, 22, 23, 26, 27, 28 \& 29 (NY, 2003), Tryon \& Tryon 5491 (MO, 1956), Tryon \& Tryon 5492 (MO, 1956), Tryon \& Tryon 5495 (MO, 1956), Tryon \& Tryon 5496 (MO, 1956), Wright 1463 (MO, 1859).

\section{Zamia integrifolia L.f.}

Alexander (FTG, 1981), Blanton \& O'Neill 6921 (MGR \& PENN, 1931), Brace 3693 (NY, 1905), Brace 6990 (NY, 1907), Brace 6991 (NY, 1907), Britton \& Millspaugh 2576 (NY, 1905), Britton \& Wilson 5443 (NY, 1910), Britton et al. 5925 (NY, 1910), Britton et al. 1911 (US, 1911), Britton et al. 10233 (NY, 1911), Bros. Leon \& Alain 18934 (GH, 1939), Carabia 1939 (F, 1939), Carabia 4102 (F, 1940), Curtiss 2676 (GH, 1911), Collins, 237 (NY, 1898), Collins 44017 (GH, 1917), Cooley et al. 9322 (GH, 1962), Correll \& Popenoe 42713 (FTG, 1974), Correll et al. 47030 (FTG, 1976), Fantz 413 (FTG, 1979), Fantz 3904 (FTG, 1979), Fantz 4137 (FTG, 1979), Godfrey \& Redfearn 52817 (GH, 1955), Godfrey \& Redfearn 52834 (GH, NY, 1955), Garber (US, 1877), Hamilton 179 (NY, 1902), Hanson et al. 10748 (FTG, 1985), Harbison 57 (AAH, 1918), Hawkes 8098 (US, 1898), Hill 2334 (FTG, 1974), Hill 2513 (FTG, 1975), Hill 11090 (NY, 1982), Howard et al. 290 (AAH, 1950), Haynes JLH05-040 (FTG, 2005), JLH05-046, JLH05-054, JLH05-075, JLH05-106, JLH05-115, JLH05-130, JLH05-145, JLH05-197, JLH05-206, JLH05-217, JLH05223, JLH05-235, JLH05-261, JLH05-270, JLH05-288 \& JLH05-301, Jack 5962 (NY, 1927), Jack (AAH, 1932), Jones (US, 1920), Landry \& LaFrankie 40 (GH, 1979), Landry \& LaFrankie 42 (GH \& MGR, 1979), Landry \& LaFrankie 43 (GH \& MGR, 1979), Landry \& LaFrankie 
44 (GH \& MGR, 1979), Landry \& LaFrankie 45 (AAH \& MGR, 1979), Landry \& LaFrankie 46 (GH \& MGR, 1979), Landry \& LaFrankie 47 (GH \& MGR, 1979), Landry \& LaFrankie 49 (GH, 1979), Leon 16294 (GH, 1935), McFarlin 6349 (MGR, 1931), Mills (US, 1926), Norstog 728 (FTG, 1972), Norstog 932 (FTG, 1972), Northrop \& Northrop 550 (NY, 1890), O'Neill (US, 1929), Ostenfeld 155 (LE, 1922), Pilsbey (PENN, 1937), Popenoe 1704 (FTG, 1979), Proctor 31556 (NY, 2003), Rolfs (NY, 1904), Safford (NY, 1917), Sargent (AAH, 1886), Seibert 1416 (PENN, 1940), Shafer 911 (NY, 1903), Shafer 1406 (NY, 1909), Simpson 394 (US, 1891), Small \& Carter 8909 (NY, 1910), Smith 522 (US \& PENN, 1882), Smith (PENN, 1892), Sturtevant 14 (MGR, 1959), Thorne \& Benny 44398 (NY, 1974), Tracey 9265 (BM, NY \& US,1904), Tryon \& Tryon 5498, 6497 (MO, 1956), Turnbull 30, 31, 33 \& 35 (NY, 2003), U.O.S. 999 (PENN, 1892), Van Hermann 913 (NY, 1905), Van Hermann 1940 (F, 1940), Walker 1588 (PENN, 1940), Walker 1865 (PENN, 1940), Woods, Coral \& Rock 5733 (NY, 1919), Wright 1463 (GH, NY \& P, 1859).

\section{Zamia lecointei Ducke}

Arbelá et al. 644 (HUA, 1996), Bernal et al. 1237 (COL, 1986), Bernal et al.1239 (COL, 1986), Bernal et al. 1240 (COL, 1986), Cortes \& Rodriguez 611 (TARA 133) (COL, 1993), Ducke 914 (MO, 1941), Duke 915 (NY, AHUC \& US, 1941), Duke 17889 (U \& K 1922), Duke 17889 (K, 1929), Duke 17890 (U \& US, 1925), Galeano et al. 661976 (NY, 1976), Huber \& Guanchez 134690 (VEN, 1980), Madison et al. 6379 (SEL, 1978), Plowman \& Guánchez 13767 (NY, 1984), Plowman \& Guánchez 13768 (NY, 1984), Schultes 12101 (GH, 1951), Schultes 12465 (COL, 1951), Schultes 13511 (GH, 1951), Schultes 14640 (GH, 1951), Schultes \& Cabrera 14956 (NY, 1952), Schultes 17663 (GH, 1952), Schultes \& Cabrera 17663 (GH, 1952), Steyermark \& Bunting 85607 (VEN, 1970), Steyermark \& Bunting 102563 (K, US \& VEN, 1970), Wurdack \& Adderley 43526 (NY \& VEN, 1959).

\section{Zamia manicata Linden ex Regel}

Alzate \& Cardona 1265-A (HUA, 2001), Betancur et al. 5999 (HUA, 1995), Burch 1112 (MO \& US, 1966), Callejas et al. 5772 (NY, 1987), Duke \& Kirkbride Jr 14000 (NY, 1967), Fonnegra et al. 6128 (HUA, 1996), Fonnegra G. et al. 6841 (HUA, 1999), Forero 1.577 (COL, 1976), Forero 1.614 (COL, 1976), Gentry \& Aguirre 15190 (MO, 1975), Hahn 155 (MO, 1980), Leon 572 (MO, 1976), Rentería et al. 3943 (HUA, 1985), Rentería et al. 10981 (HUA, 1995), Rentería et al. 10929 (HUA, 1995), Santa \& Brand 835 (HUA \& COL 1983), Schultes 18640 (GH, 1953), Schultes 18694 (GH, 1953), Schultes 18676 (GH, 1953), Stevenson et al. 604 (NY, 1984), Trujillo et al. 18244 (NY, 1983), Zuluaga R. 1033 (COL, 1983).

\section{Zamia muricata Willd.}

Allen 3355 (MO, 1945), Auitegmita \& Gammei 1175 (VEN, 1952), Bernardi 6934 (VEN, 1959), Callejas \& Marulanda 5911 (MO, 1988), Curran 1984 (NY, 1946), Curran 1813 (NY, 1952), Diaz \& Calderon 357 (NY, 1991), Folotats 3047 (VEN, 1952), Galitán et al. 83 (COAH, 2002), Gallejas \& Marulanda 5911 (HUA, 1988), González 1092 (VEN, 1977), Haught 2601 (COL \& US, 1939), Liesner et al. 7823 (MO, 1979), Pittier 9947 (US, 1921), Pittier 13965 (F, NY \& US, 1937), Prance et al. 14539 (NY, 1971), Ramírez Arango et al. 7701 (COAH, 2004), Ramírez Arango et al. 8154 (COAH, 2004), Ramírez Arango et al. 8356 (COAH, 2004), Saravia \& de Saravia 3584 (COL \& US, 1964), Smith V879 (VEN, 1967), Steyermark 55557 (F, 1944), Steyermark \& Steyermark 69911 (VEN, 1966), Steyermark \& Manara 110702 (NY, 1974), Steyermark \& Manara 110435 (VEN, 1974), Steyermark \& Gonzales 113724 (F \& VEN, 1977), Steyermark et al. 131608 (NY, 1985), Stevenson 2112 (CR, 1998), Steward et al. P12944 (NY, 1971), Sugden 211 (COL, 1977), Sugden 238 (COL, 1977), Tamayo 2198 (US, 1942), Williams 13802 (F \& VEN 1942). 


\section{Zamia neurophyllidia D.W.Stev.}

Burger 3877 (BM \& NY, 1966), Calonje et al. MAC06-04 (FTG, 2006), Calonje et al. MAC0623 (FTG, 2006), Calonje et al. MAC06-31 (FTG, 2006), Calonje et al. MAC06-34 (FTG, 2006), Cascante et al. 339 (CR, 1994), Haber \& Bello 1817 (CR, 1987), Hammer 102 (FTG, 1986), Hammer 57 (FTG, 1985), Herrera 1180 (CR, 1987), Maas 1061 (NY \& U, 1974), Molina et al. 17395 (NY, 1966), Lent 621 (CR, 1965), Robles 1548 (CR, 1988), Stevens 23771 (CR, 1986), Taylor 4380 (NY, 1967), Taylor 18125 (NY, 1975).

\section{Zamia pumila $\mathrm{L}$.}

Abbott 1158 (US, 1921), Allard 13572 (US, 1905), Armour 819 (COL, 1898), Britton \& Cowell 1336 (US, 1906), Britton \& Marble 1278 (NY, 1913), Britton et al. 1768 (NY, 1913), Britton \& Cowell 2038 (NY, 1914), Britton \& Cowell 2092 (NY \& US, 1914), Britton \& Britton 9282 (NY, 1920), Britton et al. 6912 (NY, 1922), Britton et al. 8274 (NY, 1925), Britton et al. 8299 (NY, 1925), Calonje et al. DR09-004 (FTG, 2009), Calonje et al. DR09-005 (FT, 2009), Calonje et al. DR09-008 (FTG, 2009), Calonje et al. DR09-026 (FTG, 2009), Calonje et al. DR09-033 (FTG, 2009), Calonje et al. DR09-035 (FTG, 2009), Chrysler 9261 (NY, 1924), Dod \& Zanoni 10045 (FTG, 1980), Ekman 5800 (GH, 1926), Farris 582, (US, 1921), Garcia \& Pimentel 1050 (NY, 1986), Howard \& Howard 3774 (NY, 1946), Howard \& Howard 9774 (US, 1946), Howard \& Howard 9494 (JBSD, 1946), Howard \& Howard 9495 (GH, 1946), Husaw 4170 (NY, 1920), Jack 4544 (US, 1927), Kena (NY, 1926), Liogier, 12341 (NY, 1968), Liogier 14383 (US, 1969), Mejia \& Zanoni 5081 (NY, 1980), Mejia \& Zanoni 6204 (NY, 1980), Mejia et al. 8930 (JBSD \& FTG, 1980), Mejia \& Zanoni 9145 (NY \& FTG, 1980), Mejia \& Zanoni 9404 (JBSD \& FTG 1980), Mejía et al. 13075 (FTG \& NY, 1981), Miller 1001 (US, 1908), Pelaez 1651 (NY, 1983), Rose 3707 (NY, 1913), Rose 3783 (US \& NY 1913), Shafer 2789, 793, 896, 679 \& 2659 (NY, 1909), Stimson 3816 (NY, 1966), Taylor 112 (NY, 1909), Taylor 352 (NY, 1909), Van Hermann 2652 (NY, 1906), Watson 901 (FTG, 1981), Wright 1463 (LE, 1859), Wright et al. (US, 1871), Wright et al. 873 (US, 1871), Zanoni et al. 10624 (FTG \& NY 1981), Zanoni \& Pelaez 16221 (NY, 1981), Zanoni \& Mejia 17082 (NY, 1981), Zanoni \& Pimentel 18512 (FTG, 1981 Zanoni \& Pimentel 18513 (NY, 1981), Zanoni \& Pimentel 18514 (NY, 1981), Zanoni et al. 21138 (NY, 1982), Zanoni \& Pimentel 32659 (JBSD \& NY, 1984), Zanoni et al. 29263 (NY, 1984), Zanoni et al. 34348 (NY, 1985), Zanoni \& Mejia et al. 34295 (NY, 1985).

\section{Zamia pygmaea Sims}

Acana 4122 (F, 1940), Ageay 2928 (NY, 1929), Baker 1907 (NY, 1912), Britton et al. 638 (NY, 1903), Britton et al. 803 (NY, 1903), Britton et al. 6105 (NY, 1910), Britton et al. 6105a (NY, 1910), Britton et al. 7392 (NY, 1910), Britton et al. 6267 (NY, 1910), Britton et al. 9664 (NY, 1911), Britton et al. 14166 (NY, 1916), Bro. Léon. 14764 (F, 1940), Caldwell \& Backer 7157 (F, 1907), Carabia 738 (F, 1939), Carabia 1902 (F, 1939), Carabia 3924 (F, 1940), Carabia 4009 (F, 1940), Combs 649 (GH, 1895), Dahlgren 1266174 (F, 1948), Gallardo 1708 (F, 1939), Gallardo \& Leon 17611 (F, 1940), Jack 4017 (US, 1926), Jean 4583 (P, 1914), Killip \& Swetland 41612 (US, 1951), Killip 42674 (GH, 1953), Killip 43515 (GH, 1954), Killip 44071 (US, 1954), Leon 1317 (NY, 1909), Leon \& Carabia 19014 (F, 1939), Leon \& Liogier 4583 (NY, 1914), Luca 585 (NY, 1920), Leon \& Carabia 1884 (F, 1939), Leon 18890 (F, 1939), Nalsingham (NY, 1933), Nateson 19400 (F, 1937), Palmer \& Riley 454 (NY, 1900), Palmer 16254 (F, 1935), Shafer 10652 (NY, 1911), Shafer 10715 (NY, 1911), Tryon \& Tryon 5494 (MO, 1956), Van Hermann 744 (F, 1905), Van Hermann 7130 (F, 1907), Van Hermann 7156 (F, 1907), Van Hermann 7160 (F, 1940), Wilson 9407 (NY, 1910), Wright 3193 (US, 1928). 


\section{Zamia roezlii Linden}

Bernal \& Galeano 892 (COL, 1985), Bernal \& Correndor 1459 (COL, 1988), Cuatrecasas 14318 (COL, 1943), Cuatrecasas 16868 (COL \& MO, 1944), Cuatrecasas 21902 (NY \& MO, 1967), Cuatrecasas \& Patino 27459 (NY, 1969) Fuchs et al. 21902 (COL, 1967), Fuchs et al. 21903 (COL, 1967), Fuchs et al. 22107 (COL \& K, 1967), Gentry et al. 53395 (MO \& NY, 1985), Kiem \& Norstog 38, (FTG, 1976), Killip \& Cuatrecasas 39129 (COL, 1944), Killip \& Cuatrecasas 38967 (COL, US \& F, 1944), Killip \& Garcia 33337 (COL \& F, 1939).

\section{APPENDIX 2}

GenBank accession numbers for the species examined in this study

APPENDix TABLE 1. GenBank accession numbers

\begin{tabular}{|c|c|}
\hline Species (identification no.) and markers & GenBank no. \\
\hline \multicolumn{2}{|l|}{ Ceratozamia robusta Miq. (d1105) } \\
\hline $26 \mathrm{~S}$ & KX503762 \\
\hline$C A B$ & KX503773 \\
\hline matK & KX503752 \\
\hline NEEDLY & KX503784 \\
\hline$r b c L$ & KX503803 \\
\hline \multicolumn{2}{|l|}{ Microcycas calocoma (Miq.) A.DC. (d1063) } \\
\hline $26 \mathrm{~S}$ & KF221117 \\
\hline$C A B$ & KF221128 \\
\hline matK & GQ203854 \\
\hline NEEDLY & GQ203954 \\
\hline$r b c L$ & KF221191 \\
\hline \multicolumn{2}{|l|}{ Zamia acuminata Oerst. ex Dyer (d1064) } \\
\hline $26 \mathrm{~S}$ & KX503772 \\
\hline$C A B$ & KX503774 \\
\hline matK & GQ203856 \\
\hline NEEDLY & GQ203963 \\
\hline$r b c L$ & KX503804 \\
\hline \multicolumn{2}{|l|}{ Zamia angustifolia Jacq. (d1066) } \\
\hline $26 \mathrm{~S}$ & KF221119 \\
\hline$C A B$ & KF221130 \\
\hline matK & GQ203857 \\
\hline NEEDLY & GQ203957 \\
\hline$r b c L$ & KF221193 \\
\hline \multicolumn{2}{|c|}{ Zamia erosa O.F.Cook \& G.N.Collins (d1065) } \\
\hline $26 \mathrm{~S}$ & KX503765 \\
\hline$C A B$ & KX503777 \\
\hline matK & KX503756 \\
\hline NEEDLY & KX503786 \\
\hline$r b c L$ & KX503800 \\
\hline \multicolumn{2}{|l|}{ Zamia integrifolia L.f. (CC245) } \\
\hline $26 \mathrm{~S}$ & KX503764 \\
\hline$C A B$ & KX503775 \\
\hline
\end{tabular}


Appendix table 1. (Continued)

\begin{tabular}{|c|c|}
\hline Species (identification no.) and markers & GenBank no. \\
\hline matK & KX503755 \\
\hline NEEDLY & KX503788 \\
\hline$r b c L$ & KX503799 \\
\hline \multicolumn{2}{|l|}{ Zamia lecointei Ducke (d1152) } \\
\hline $26 \mathrm{~S}$ & KX503767 \\
\hline$C A B$ & KX503783 \\
\hline matK & KX503760 \\
\hline NEEDLY & KX503791 \\
\hline$r b c L$ & KX503795 \\
\hline \multicolumn{2}{|l|}{ Zamia manicata Linden ex Regel (d1153) } \\
\hline $26 \mathrm{~S}$ & KX503768 \\
\hline$C A B$ & KX503782 \\
\hline matK & KX503758 \\
\hline NEEDLY & KX503790 \\
\hline$r b c L$ & KX503797 \\
\hline \multicolumn{2}{|l|}{ Zamia muricata Willd. (d1075) } \\
\hline $26 \mathrm{~S}$ & KX503769 \\
\hline$C A B$ & KX503781 \\
\hline matK & KX503759 \\
\hline NEEDLY & KX503793 \\
\hline$r b c L$ & KX503794 \\
\hline \multicolumn{2}{|l|}{ Zamia neurophyllidia D.W.Stev. (d1076) } \\
\hline $26 \mathrm{~S}$ & KX503771 \\
\hline$C A B$ & KX503778 \\
\hline matK & KX503753 \\
\hline$N E E D L Y$ & KX503789 \\
\hline$r b c L$ & KX503798 \\
\hline \multicolumn{2}{|l|}{ Zamia pumila L. (d1100) } \\
\hline $26 \mathrm{~S}$ & KX503766 \\
\hline$C A B$ & KX503776 \\
\hline matK & KX503757 \\
\hline$N E E D L Y$ & KX503787 \\
\hline$r b c L$ & KX503801 \\
\hline \multicolumn{2}{|l|}{ Zamia pygmaea Sims (CC253) } \\
\hline $26 \mathrm{~S}$ & KX503763 \\
\hline$C A B$ & KX503779 \\
\hline matK & KX503754 \\
\hline NEEDLY & KX503785 \\
\hline$r b c L$ & KX503802 \\
\hline \multicolumn{2}{|l|}{ Zamia roezlii Linden (d1082) } \\
\hline $26 \mathrm{~S}$ & KX503770 \\
\hline$C A B$ & KX503780 \\
\hline matK & KX503761 \\
\hline NEEDLY & KX503792 \\
\hline$r b c L$ & KX503796 \\
\hline
\end{tabular}

